\title{
EGFR NP_005219.2:p.D770_N771insAPW
}

National Cancer Institute

\section{Source}

National Cancer Institute. EGFR NP 005219.2:p.D770 N771insAPW. NCI Thesaurus.

Code $C 98635$.

An insertion of the amino acid sequence alanine-proline-tryptophan between the aspartic acid at position 770 and the asparagine at position 771 of the epidermal growth factor receptor protein. 